\title{
A NOÇÃO DE "METAFÍSICA” A PARTIR DO ARCABOUÇO TEÓRICO DO SEGUNDO PERÍODO DA OBRA NIETZSCHIANA
}

\author{
Tiago Eurico de Lacerda ${ }^{1}$
}

RESUMO: O artigo apresenta as noções de metafísica a partir dos textos do segundo período dos escritos nietzschianos. O objetivo central é analisar como Nietzsche implementa sua crítica à metafísica apontando-a como fruto de uma falsa interpretação daquilo que é propriamente humano. Assim dos usos da palavra metafísica que Nietzsche utiliza em suas obras ater-nos-emos ao sentido crítico onde a metafísica se caracteriza como hostilidade à sensibilidade, a valorização do suprassensível, a crença no incondicionado e a anulação da interpretação que possibilita pensar a crença numa verdade pura e única. A problemática ocorre quando o homem se esquece de que a vida não é compatível com o ultramundo inventado repleto de ideais. A consequência disso é um desgosto consigo mesmo e um sentimento de culpa levando o homem a querer outra vida e outro lugar concedendo valor ao além em detrimento de todo aquém. Para se contrapor a essa culpa Nietzsche propõe o inverso: se por um lado o homem se acha responsável e culpado, pois não se vê pelo viés da necessidade, o projeto de Nietzsche aponta para a Inocência do devir, mas que leva o homem a se desprender da culpa porque passa a olhar para si e para o mundo de forma mais "correta". 
PALAVRAS-CHAVE:Metafísica; Religião; Procedimento Científico; Necessidade.

ABSTRACT: The article provides the concepts of metaphysics from the texts of the second period of Nietzschean writings. The central objective is to examine how Nietzsche implements his critique of metaphysics indicated as the result of a false interpretation of what is properly human. So of the uses of the word metaphysics that Nietzsche uses in his works we will stick to the a critical sense where metaphysics is characterized as hostility to sensitivity, appreciation of the supersensible, the belief in the unconditioned and the annulment of interpretation that enables think belief in a pure and only truth. The problem occurs when man forgets that life is not compatible with other world created replete of ideals. The consequence is a disgust with oneself and a sense of guilt leading man to want another life and another place appreciating the other world in detriment of this. To confront this guilt Nietzsche proposes the opposite: if on one hand the man is responsible and guilty, because he did not realize the need, the project Nietzsche points to the innocence of becoming, but it takes the man to detach the blame because going to look at yourself and the world in the most "correct" way.

KEYWORDS: Metaphysics; Religion; Scientific Procedure; Necessity. 


\section{INTRODUÇÃO}

A análise "crítica" da metafísica realizada por Nietzsche no segundo período de sua produção está ligada à ideia de que ela não passa de uma falsa interpretação das coisas humanas. Antes de entendermos melhor o que isso significa, é preciso reconhecer que em Nietzsche não há um sentido unívoco para a palavra metafísica. Esse conceito - como, ademais, muitos outros apresenta-se de forma polissêmica e aberta, fluída e de difícil delimitação. Assim o conceito de metafísica está ligado: à ideia da existência de dois mundos que nos remete à ideia de dualidade e por esta a valorização do mundo inteligível. Para Nietzsche a metafísica está relacionada à oposição de valores, principalmente os apresentados pela filosofia de Platão (crença dualística num mundo verdadeiro) e consequentemente pela religião cristã que representa uma antítese ontológica do mundo (marcado pela mutação e contradições) em que vivemos. Segundo Camargo, o filósofo alemão denominará metafísicos os habitantes desse evanescente mundo "situado para além do sensível, [...] um 'mundo verdadeiro' por trás da 'aparência"' (2008, p. 94), como se existisse uma realidade superior por trás de todas as coisas, um conceito que abarcasse a "coisa em si" em sua forma mais pura.

É necessário salientar que a palavra ou o sentido de metafísica permeia toda a obra nietzschiana tendo uma ênfase no segundo período para direcionar o homem novamente àquilo que lhe é próprio, e que chamamos de coisas humanas. Assim a metafísica possibilitou, portanto, o alheamento e o esquecimento daquilo que está realmente na base da vida, o interesse pelo mundo e pelo corpo, pelas coisas que foram esquecidas ou negadas: podemos dizer que "há um simulado desprezo por todas as coisas que 
as pessoas consideram realmente mais importantes, por todas as coisas mais próximas" (AS, 5). ${ }^{2}$ Para Nietzsche este foi um resultado dos pensadores metafísicos que, por uma linguagem ${ }^{3}$ exagerada em prol das coisas mais distantes, ou seja, dos ideais, tidos por eles como mais importantes, colocaram de lado o que poderia servir como objeto de reflexão, tais como alimentação, moradia, vestuário, respiração, clima, relacionamentos e tudo o que é mais próximo. Pois isto não foi objeto de interesse, nem da arte, nem da filosofia ou da religião, fazendo com que "as pessoas veem mal e raramente se atentam às coisas mais próximas possíveis" (AS, 6), ao contrário, elas se expressam como tendência equivocada ao que julgam como mais importante, ou seja, as coisas mais distantes. Daí a importância em avizinharse das coisas mais próximas, pois o seu desprezo leva o próprio homem à ruína, pois este, vislumbrado pelo ideal, se deixa seduzir e esquecer não somente das coisas terrestres, mas de si próprio.

Temos que novamente nos tornar bons vizinhos das coisas mais próximas e não menosprezá-las como até agora o fizemos, erguendo o olhar para nuvens e monstros noturnos. Foi em bosques e cavernas, em solos pantanosos e sob os céus cobertos que o homem viveu por demasiado tempo, e miseravelmente, nos estágios culturais de milênios inteiros. Foi ali que aprendeu a desprezar o tempo presente, as coisas vizinhas, a vida e a si mesmo (AS, 16).

O humano aprendeu a desprezar as coisas vizinhas e com isso se afastou de si mesmo para buscar a sua "essência" e o fez não pelo caminho do que é provisório e múltiplo, mas pela busca do que é estável. "Muitas cadeias foram postas no homem para que ele desaprendesse a se comportar como um animal" (AS, 350) e 
aprendesse os erros das concepções morais e os traduzissem na forma dos conceitos, cujo resultado foi transformá-lo num animal domesticado, preso às suas inúmeras cadeias de ideais, para as quais Nietzsche dirige a sua tarefa filosófica: "agora estamos em meio ao nosso trabalho de tirar as cadeias, e nisso necessitamos o máximo de cuidado" (AS, 350). E será pelo procedimento científico que Nietzsche possibilitará uma reflexão dessas cadeias conduzindo o homem a uma naturalização de si mesmo que o desmistificará das alturas ou dos conceitos inatingíveis para reabilitá-lo às suas próprias vivências. Para isso o presente artigo apresentará a contextualização desse problema a partir do segundo período dos escritos de Nietzsche apresentando a metafísica como um erro de interpretação, uma necessidade de unidade que valoriza o suprassensível e o incondicionado em detrimento de tudo aquilo que avizinha o homem ao que lhe é mais próprio.

\section{O ARCABOUÇO TEÓRICO DO SEGUNDO PERÍODO DA OBRA NIETZSCHIANA}

Para uma questão de periodização e um recorte metodológico de nosso artigo, a reflexão apresentará o problema da metafísica no contexto do arcabouço teórico do segundo período da obra nietzschiana. O chamado "segundo período" de Nietzsche é desenvolvido durante os anos de 1876 e 1882. O primeiro volume de Humano, demasiado humano é organizado por Nietzsche durante o inverno de 1876-1877 e, posteriormente, publicado em 1878. Esse volume é seguido de dois outros: Opiniões e Sentenças e $O$ Andarilho e sua sombra, que juntos formam o livro Humano, Demasiado Humano II. Em 1881 Nietzsche publica Aurora e um ano depois A Gaia Ciência. No entanto, é importante lembrar que 
Nietzsche acrescenta novos prefácios para essas obras no ano de 1886e, em 1887, acrescentou o capítulo V a sua obra A Gaia Ciência.

Nesse período percebemos que a oposição entre arte e ciência é abandonada em detrimento de todo pensamento metafísico. Segundo Ramacciotti "nesse período surge também o projeto de A Gaia Ciência, que já apresenta a necessidade de uma nova hermenêutica filosófica pela fusão de múltiplas perspectivas de interpretação: estética, história natural, psicologia, filosofia, filologia etc" (2012, p. 88). O que veremos é que diferente da arte, a metafísica cria mundos ilusórios, mas o oferece como verdade absoluta, o que será contraposto pela ciência. Segundo Marton "o filósofo passa a tratar das relações entre religião, metafísica, arte e ciência, privilegiando sempre esta última. Sustenta que o ser humano concebeu o mundo erroneamente, pois o encarou com pretensões religiosas, estéticas ou morais" (2000, p. 205), o que será o fio condutor da crítica de Nietzsche à toda filosofia de cunho metafísica.

O que Nietzsche pretende nesse período é desmascarar as ilusões que a filosofia metafísica cria se apresentando como uma verdade absoluta e colocá-la como uma entre tantas outras interpretações, assim como se apresenta a arte, criadora de mundos ilusórios e cônscia desse papel. Segundo Oliveira:

Para efetivar essa pretensão, seria necessário [primeiro] derrotar a necessidade da verdade e [segundo] restituir o papel artístico para a tarefa filosófica. Para ambas as tarefas, Nietzsche faz uso, no chamado segundo período de sua produção (1876-1882), do 'método científico' (HH, 635), já que a meta principal seria demonstrar que a invenção da metafísica tem sua origem em erros da razão, fraquezas, idiossincrasiasepsicopatologias deseusautores (2012,p.11). 
E será justamente pelo "método científico" $(\mathrm{HH}, 635)$ que Nietzsche implementará sua desconstrução das ilusões contidas na filosofia metafísica. Esse "método" seria, assim, um exercício crítico, um procedimento científico que permitiria olhar para o mundo com a mais profunda suspeita, uma filosofia "histórica" que trabalharia a partir da "química dos conceitos e dos sentimentos" $(\mathrm{HH}, 1)$, para fazer saber que tudo aquilo que atribuímos uma origem miraculosa, tem história e não passa de coisas humanas.

\section{OS SENTIDOS DA PALAVRA METAFÍSICA EM NIETZSCHE}

Aotratar sobreossentidos da noção de metafísica em Nietzsche podemos associá-la à própria noção de "conceito" utilizada no contexto de sua crítica aos filósofos que estavam presos às verdades eternas, em seus dogmas. Com isso ele queria criticar esses ideais referindo-se sempre a algo imutável. Dessa forma um conceito seria sempre inalterável, pois não sofre a ação do processo histórico que Nietzsche empreende para uma crítica à metafísica. O que ele fará é uma análise na qual os conceitos são reinterpretados, ou seja, ganham novas significações, possibilidades, pois, da mesma forma que as palavras, os conceitos são como "bolsos, nos quais se guardou ora isto, ora aquilo, ora várias coisas de uma vez!" (AS, 33), portanto, algo efêmero que se modifica no tempo e não se guarda em um lugar, como uma ideia fixa, mas está em um constante devir, resultado das mais variadas forças.

Dessa forma o conceito é por si mesmo, um elemento metafísico, porque está desligado da história e nisso contribui para que a própria metafísica seja não outra coisa que a história de um erro - como explicitaremos neste artigo. Como expressão 
de negação ${ }^{4}$ da vida, os "conceitos" querem expressar aquilo que está desligado da existência concreta e só tem algum sentido como expressão de ideias suprassensíveis. A vida, de seu lado, é caracterizada pelo movimento e não pela estabilidade: "tudo o que vive se movimenta; e essa atividade não se deve a determinados objetivos, ela éa própria vida" (KSA 9, 1 [70], de 1880,p.21). Ou seja, a vida não é estática e fixa, está num constante devir, e juntamente com ela, o homem e os conceitos, pois nada é eterno, tudo pode ser reinterpretado e tomar nova cor, novo tom. Como formas de interpretação da vida, os conceitos (ou mais genericamente, as palavras) são sintomas dos eventos fisiológicos ${ }^{5}$ dos seres humanos e sua origem está ligada às vivências mais próximas.

Do ponto de vista do uso da palavra metafísica em Nietzsche, podemos afirmar que em sua obra ela aparece de dois modos: um uso positivo, empregado geralmente pelo filósofo para caracterizar a própria filosofia do primeiro período de seus escritos; e um uso crítico, tal como aquele que ocorre nos textos do segundo período. Por questões de cunho didático, que estão ligadas ao objetivo e à delimitação da problemática do presente artigo, aternos-emos ao segundo uso, a partir do qual levantaremos algumas características daquilo que Nietzsche entende por metafísica.

Quanto à constância do termo na obra do filósofo alemão, pode-sefacilmenteconstatarqueéno segundo período(justamente à época de Humano, demasiado humano) que a palavra metafísica aparece com mais força e evidência, principalmente na primeira seção da obra (contra apenas 8 citações em GC, 8 em BM; 4 em GM; e 3 em CI). Segundo Wotling estas citações são mínimas, se comparadasao número de ocorrências deexpressões como "moral", "filosofia", "razão", "instinto" (2008, p. 56), etc. Em princípio parece que a "metafísica" não é uma noção que tenha merecido tanta atenção por parte de Nietzsche. O aforismo Das coisas primeiras e últimas que abre Humano, demasiado humano é um dos quais 
o termo aparece com evidência, para se desbotar novamente nas obras posteriores, nas quais o termo raramente aparece.

Entre os sentidos que caracterizam o uso da palavra metafísica por parte de Nietzsche estão a hostilidade à sensibilidade; a sobrevalorização da racionalidade; criação de dois mundos; a valorização do mundo suprassensível em detrimento do sensível; a busca pela unidade, pela verdade e por uma monadologia, contra a multiplicidade e complexidade; a necessidade de segurança; a crença na verdade como busca pela familiarização; o repouso absoluto (depois isso pode ser colocado no âmbito da promessa religiosa de redenção no reino de Deus); a intransigência e fanatismo na busca da verdade; o atomismo; o dualismo; o pensamento unitário; a anulação da interpretação como função filosófica pela via da verdade pura e única.

Não é nosso intuito analisar, nesse trabalho, todas essas nuances. Ainda assim, segundo nossa interpretação, elas podem ser reunidas na ideia de que todas evocam um "erro de interpretação" que valoriza a essência das coisas em detrimento da aparência, algo que é interpretado por Nietzsche como uma "necessidade metafísica" ( $\mathrm{HH}, 26)$ que revela em sua forma mais funesta a alma como uma realidade indivisível, indestrutível, como uma mônada (uma substância simples, sem partes), como um átomo, em consequência de uma desvalorização do corpo e do mundo concreto dos fenômenos humanos. As outras nuances do termo devem, portanto, ser entendidas como desdobramentos desse "erro" inicial.

\section{A METAFÍSICA COMO "ERRO DE INTERPRETAÇÃO"}

Para compreendermos melhor como Nietzsche analisa a metafísica para criticá-la é preciso observar: primeiro, a 
ideia de oposição e segundo, a ideia de valoração que nasce da oposição - duas ideias centrais da metafísica analisadas já no primeiro aforismo de Humano, demasiado humano. Nietzsche mostra que os aparentes opostos não passam de ficções e "erros de interpretação". ${ }^{6}$ Nietzsche parte, assim, da constatação de que "não há opostos, salvo no exagero da concepção popular ou metafísica" $(\mathrm{HH}, 1)$. É só como visão popular ou metafísica que essa ideia permanece, pois falta à visão popular o espírito "científico", algo que também teria contaminado toda a história da filosofia. Ora, o que pode parecer como uma oposição entre contrários, por exemplo, o irracional do racional, ou ainda noções como belo e feio, quando submetidos à luz daquilo que Nietzsche entende e pratica como ciência, perdem toda validade, pois na base dessa contraposição fundante da metafísica, estão erros da razão que serão desmistificados através do procedimento científico de Nietzsche a partir da história e da psicologia.

A crítica de Nietzsche, assim, remete à ideia de que a metafísica está ligada a uma tentativa de fixar um sentido, uma verdade ou mesmo uma meta única e é contra isso que o autor lança a sua crítica - aos que, hostis à sensibilidade humana, tecem mundos onde o homem não pode experimentar a própria vida, mas deve simplesmente pensá-la de forma racional. Para o Nietzsche de Humano, demasiado humano, a metafísica não passaria de emprego de hipóteses e crenças que, por sua pretensão de verdade (tida por ele como falsa, como veremos mais adiante), desviam o valor do conhecimento ao que fixo, deixando de lado as possibilidades de interpretações e experimentações que fazem parte da vida concreta baseada no devir.

Como busca fixa pela verdade, a metafísica leva o homem a um princípio detrator da vida: a crença metafísica que entende 
a busca pela verdade em sentido absoluto, conduz o homem aos "erros de interpretação" $(\mathrm{HH}, 111)$ e à afirmação de outro mundo que não o da vida constituída na história e em devir. Por isso mesmo, o "método" proposto por Nietzsche, privilegia de tal maneira o elemento histórico (ele mesmo chama o seu procedimento de "filosofia histórica" $[\mathrm{HH}, 1])$ : o esquecimento da história é a marca da metafísica porque ela acredita que suas verdades advém de um mundo além, suprassensível, pelo qual o homem passa a valorizar de forma demasiada a racionalidade em detrimento da própria experiência e vida.

Essa supervalorização da racionalidade, portanto, é que levou o homem aos "erros da razão" $(\mathrm{HH}, 133)$, que nada mais seria, conforme já afirmamos, do que um resultado dos "erros de interpretação" $(\mathrm{HH}, 111)$ - constituindo assim bases para que a moral se estabelecesse e criasse a possibilidade da dualidade não só do homem e da vida, mas da verdade, atribuindo valores ao racional em detrimento do sensível, corporal, das coisas humanas.

Esses erros, sobre os quais toda a história da metafísica (e, consequentemente, da religião e da moral) se ampararam, não passariam de uma visão distorcida, fruto da imaginação errada e do mau juízo humano. O que Nietzsche busca com seu "método" é dissipar as crenças e ficções advindas da metafísica desde Platão, e em contraposição a este, mostrar que a sabedoria não está em conquistar o conhecimento sobre o que é fixo (aos moldes da ideia e do conceito), mas no que é, justamente, passageiro como se apresenta a ideia do andarilho que não "pode atrelar o coração com muita firmeza a nada em particular; nele deve existir algo de errante, que tenha alegria na mudança e na passagem" (HH, 638). Sua visão não contempla aquilo que permanece inalterado, mas busca um constante fluir de todas as coisas. 
A NOÇÃO DE "METAFÍSICA"A PARTIR DO ARCABOUÇO TEÓRICO DO SEGUNDO...

Ao pensar o homem de forma fixa, se olvida que ele é fruto de um processo histórico que engloba a ação da religião, da ciência, da arte e etc. Esse esquecimento de que as coisas tem uma história fez com que fosse inventado o ser perfeito e eterno, nas suas variadas formas de apresentação metafísica.

Sendoassim - insistimos - éimportantedestacarque, quando se trata de analisar os usos feitos por Nietzsche da palavra metafísica no segundo período de sua produção filosófica, o que fica evidente é que, com esse termo Nietzsche designa uma série de "erros de interpretação" ou "erros da razão" (HH, 133) quelevaram o homem a inventar mundos à parte. É nesses termos que a religião aparece como uma avaliação errada dos fenômenos humanos os quais, ao invés de serem submetidos à análise científica do procedimento nietzschiano acabaram sendo interpretados erroneamente pelo viés metafísico, frutos de uma filosofia ideal e dogmática.

Para superar a metafísica e deixar para trás as crenças religiosas (anjos, pecado original, salvação das almas) é preciso um esforço e segundo Nietzsche se faz necessário um "movimento para trás: ${ }^{7}$ em tais representações ele tem de compreender a justificação histórica e igualmente a psicológica" $(\mathrm{HH}, 20)$ para se livrar desses erros e encontrar um caminho mais verdadeiro de análise da própria vida. Mas como devemos entender esse "erro" ao qual Nietzsche contrapõe, no segundo período de seus escritos, a sua "verdade" científica ou o seu "método rigoroso" $(\mathrm{HH}, 3)$ ? Estaria Nietzsche, defendendo a sua própria interpretação como detentora de uma verdade e, sendo assim, recaindo no próprio erro que ele mesmo critica? Seria Nietzsche tão ingênuo? E mais, estaríamos autorizados a intitular sua filosofia, nesse segundo período, de filosofia iluminista ou mesmo positivista? Partimos do ponto de vista de que as respostas a essas questões 
são negativas, pois existiria em Nietzsche uma crítica ao erro da metafísica no sentido de que esse erro é a negação de seu caráter ilusório, interpretativo ou mesmo criativo-artístico. Em outras palavras: ao denunciar o erro das interpretações metafísicas, Nietzsche não está negando o fato de que os erros são "necessários à vida" $(\mathrm{HH}, 33)$ ou mesmo que há uma necessidade deles $(\mathrm{HH}$, 31 e 32). O erro da metafísica é negar essa possibilidade, negar o fato de que ela é uma ilusão e, tal como a arte, ela também nasce de necessidades "ilógicas" ( $\mathrm{HH}, 31)$ e "injustas" ( $\mathrm{HH}, 32)$ que estão ligadas à vida. Ao contrário, a filosofia histórica, reconhece esse papel interpretativo e "errado" que ela mesma contém. A metafísica, ao contrário, nega essa perspectiva porque pretende uma "verdade" única. Portanto, a verdade que Nietzsche contrapõe ao erro é uma "grande verdade", ou seja, aquela que rompe com as divergências entre verdade e mentira por reconhecer que todas as verdades não passam de ilusões. Isso porque, a verdade é entendida, por Nietzsche, como uma invenção. Pois ao criar o arcabouço de uma verdade única ela cria mundos ilusórios e projeções de aparências que negam a si mesma como tais.

Segundo Oliveira, “o que falta à metafísica é a 'consciência' de seu erro, a capacidade de reconhecer o quanto de ilusão, ficção, fantasmagoria e mesmo alucinação residem em seu âmago" (2012, p. 26), pois se assim o fizesse viver das aparências não seria em si uma vida a partir da mentira, mas da tentativa de tornar a vida leve como fazem os artistas pela arte tecendo mundos fabulosos, mas cônscios dessas fábulas para que a tensão da vida se torne mais flexível e passível de infinitas interpretações. Em A Gaia Ciência Nietzsche esclarece que o homem foi educado por seus erros, mas que "excluindo o efeito desses erros, exclui-se também humanidade, humanismo e "dignidade humana" (GC, 
115). Noutro aforismo o filósofo aponta que foram justamente esses erros que o intelecto humano produziu durante séculos que se "revelaram úteis e ajudaram a conservar a espécie" (GC, 110) e somente muito depois segundo Nietzsche é que surgiu a verdade como a mais fraca forma de conhecimento.

\section{A METAFÍSICA COMO NECESSIDADE DE UNIDADE}

As ideias metafísicas partem de crenças de que, primeiro, há "coisas iguais" e, segundo, "a crença primeira de todo ser orgânico, desde o princípio, é talvez a de que todo o mundo restante é uno e imóvel”. (HH, 18). Há uma preocupação de se pensar a unidade mesmo estando em meio à multiplicidade e às "correntes com muitas fontes e afluentes" (HH, 14). Para Nietzsche, os indivíduos só pensam assim porque pensam a vida isolada e desconexa de outras experiências anteriores. Porém, "na medida em que a metafísica se ocupou principalmente da substância ${ }^{8}$, podemos designá-la como a ciência que trata dos erros fundamentais do homem, mas como se fossem verdades fundamentais" ( $\mathrm{HH}, 18)$. Esses erros fundamentais se baseiam em atribuir ao mundo e às coisas uma essência, uma característica fixa e uma e de forma absoluta. Referindo-seaomundometafísico Nietzscheexplicitaque "é verdade que ele poderia existir; dificilmente podemos contestar a sua possibilidade absoluta" ( $\mathrm{HH}, 39)$. O problema central não se fixa na possibilidade de existência do pensamento metafísico, mas sim em se impor como uma verdade absoluta, revelando uma identidade irrevogável. Trata-se de uma "necessidade de unidade" que marca o pensamento metafísico equeérecusada por Nietzsche:

O dualismo não é, contudo, nem a derradeira palavra

e nem a raiz última. Uma necessidade de unidade 
que atravessa todo exercício do pensamento tal como realizado pela metafísica, que lhe informa constantemente, mas secretamente, é este que Nietzsche chama constantemente de "atomismo" (WOTLING, 2008, p. 64).

O atomismo é uma necessidade violenta pela unidade que perpassa todo o pensamento metafísico aprovando esta forma de pensar como verdade ou respostas satisfatórias. Nietzsche refuta ao atomismo e assegura que esta "necessidade atômica" ainda sobrevive da forma mais perigosa na "necessidade metafísica" e que é preciso resistir-lhe como uma a guerra. Todas estas crenças, Nietzsche as ataca com o objetivo de destruílas, por isso a proposta de inversão do platonismo. O próprio Nietzsche define sua filosofia como um "platonismo invertido" em um fragmento póstumo de 1870-1871 (KSA 7, 7 [156], p. 199). Por isso, todo o projeto implementado por Nietzsche em seu segundo período de produção está ligado a esta definição. Sobre essa inversão do platonismo podemos ainda dizer que a compreensão de metafísica, segundo essa interpretação, está ligada ao pensamento de Platão e à tentativa de Nietzsche em se opor a ela, causando o que chamamos de inversão do platonismo. Sobre esse assunto existem algumas variações, no primeiro momento ressaltamos a ideia de Heidegger que pensa a filosofia de Nietzsche como uma pura inversão de medidas:

Inverter o platonismo significa então inverter a relação com que dá a medida; o que no platonismo se encontra embaixo e quer ser medido a partir do suprassensível precisa ser transposto para cima; é preciso colocar o suprassensível inversamenteaoseuserviço.Emmeioàrealizaçãodainversão, o sensível se transforma no ente propriamente dito, isto é, no verdadeiro, na verdade (HEIDEGGER, 2007, p. 140). 
Enquanto para Heidegger a inversão se baseia na mudança dos extremos, Giacóia Junior vai além dessa delimitação para expressar de uma forma mais sutil a superação da dualismo platônico não a partir da ideia de Heidegger, mas por outro viés, o da superação.

Inverter seria, então, simplesmente reverter, revalorizar o extremo oposto daquele valorizado pelo Sócrates platônico. Penso ser aqui fundamental distinguir o Nietzsche de fachada de um Nietzsche mais sutil, de intenções filosóficas abissais. Inverter o platonismo não significa, no fundo, retornar a sofística ou ao realismo cru de Tucídides, significa, antes, levá-lo além e acima de si mesmo, superálo e transfigurá-lo numa espécie de grandeza, profundidade e elevação cuja virtude não consiste na violência ou na crueldade da dominação física ou política, mas aquilo que se poderia denominar domínio de si, tornar-se senhor de seus próprios demônios (GIACÓIA JÚNIOR, 1997, p. 33).

A intenção é simplesmente destituir de seu patamar de verdade essas ideias que salientam a importância da alma de todo o mundo suprassensível e sua existência como algo indestrutível e eterno, levando posteriormente o cristianismo a aplicar em seu ideário tais estruturas fundamentando o "atomismo das almas" e toda a necessidade de se predicar o que é uno. MüllerLauter entende que "Nietzsche consiste justamente em proceder à destruição da metafísica a partir dela mesma" (1997, p. 52), pois se Nietzsche assume, por vezes ares de metafísico, por trás das aparências que inventa para si a cada momento, ele leva a metafísica a desmoronar, pois não se detém em momento algum às suas investigações. $\mathrm{O}$ desejo de um dualismo parte da metafísica e a raiz de seu escopo está em uma obsessão pela unidade. Ainda podemos tomar como predicativos da metafísica a: 
Submissão da totalidade do exercício do pensamento a um frenesi da unidade e da identidade, de paralisar as outras possibilidades interpretativas que estão abertas, para não deixá-las se exercer senão consertadas por esta finalidade única: encontrar a unidade a todo preço, inventar a unidade, construir a unidade (sem reconhecer, nem mesmo saber, que ela a construiu), conter o poder do pensamento lhe subordinando a esta obsessão do átomo (WOTLING, 2008, p. 66).

A metafísica, então, pensaria o mundo como uma "coleção de unidades, de entidades discretas, definindo-se no sentido de uma estrutura de oposição e, portanto, apreendido intelectualmente graças às oposições garantidas pela razão" (WOTLING, 2008, p. 67). Chega-se, então, à necessidade de Deus - símbolo máximo da necessidade metafísica de unidade - como anulação da multiplicidade do devir, em nome da afirmação de um Ser absoluto, colocado num mundo superior à "terra". Apresentaremos no tópico a seguir essa valorização e afirmação desse Ser absoluto suprassensível como fruto de uma má-interpretação das coisas terrestres e humanas.

\section{VALORIZAÇÃO DO SUPRASSENSÍVEL E DO INCONDICIONADO}

A valorização do suprassensível se justifica numa busca do homem de compreender a própria vida e a faz pela via da crença do além em detrimento de todo aquém. Pelo procedimento científico de Nietzsche perceberemos que essa valorização parte de uma fraqueza fisiopsicológica de enfrentamento da vida nas suas condições vitais. Essa forma de pensar a vida não passaria de 
mais uma falha interpretativa, pois o homem interpreta de forma errônea sua própria realidade. Essa forma de se perceber e ao mundo que vive gera um mal-estar devido a uma visão errônea, vê a si mesmo de forma "tão turva" (HH, 132) que projeta sua imperfeição no mundo. Buscando sempre uma vida nova no além e o próprio além como possibilidade de vida melhor que o aquém.

Assim encontramos o homem submerso na "necessidade metafísica" criando ultramundos e tecendo para si no campo moral um conjunto de regras que regerá a vida. Ocorre que este homem se esquece de que a vida não é compatível com este mundo inventado repleto de ideais e, tais metas de vida não podem ser cumpridas. Ele chega a esse estado por sua "culpa" ou "pecado" e por uma "série de erros da razão" (HH, 133) que o levou a pensar sua própria natureza de forma odiável e obscura. Assim por uma má-observação de si mesmo que o levou a um sentimento de autodesprezo ele se vê como mau e com o peso dessa culpa de não lograr a satisfação consigo mesmo. Pela análise procedimental nietzschiana o homem poderá se contrapor a essa culpa compreendendo sua realidade mais próxima, pois estará cônscio que age no campo da necessidade e poderá propor o inverso: se por um lado o homem se acha responsável e culpado, o projeto de Nietzsche aponta para a Inocência do devir que leva o homem a se desprender da culpa porque passa a olhar para si e para o mundo de forma mais "correta".

SegundoNietzsche"se, porfim, a pessoaconquistareincorporar totalmente a convicção filosófica da necessidade incondicional de todas as ações e de sua completa irresponsabilidade, desaparecerá também esse resíduo de remorso" (HH, 133), ou seja, ela precisa se convencer da necessidade de seus atos para superar a sua culpa e todo tipo de mal-estar. Pois este mal-estar gerado no homem 
pela culpa tem sua origem na moral da compaixão $0^{9}$ que afirma que "todo homem é concebido e gerado em pecado" (HH, 141). Este pecado seria resultado do livre-arbítrio, que ainda tem lugar especial na moral schopenhauriana contra a qual Nietzsche se volta nesse momento: segundo o autor de Humano, demasiado humano, é pela ilusão do livre-arbítrio, ou seja, pela interpretação de que o homem poderia escolher livremente as suas ações que ele seria culpado por elas. Ao afirmar que tudo é necessidade, Nietzsche evoca outro princípio para a avaliação das ações humanas: um princípio ligado à vida, na qual ao invés da culpa, haverá inocência, caminho pelo qual o homem poderá se desprender dessa valorização do suprassensível para perceber a si mesmo e ao mundo em que vive sem as pretensões religiosas ou metafísicas.

Ao contrário disso, para Nietzsche é vontade da própria religião e dos metafísicos fazer que o homem se ache ruim e pecador, assim com o passar dos anos ele se sente tão oprimido por todos os pecados cometidos que o remédio para tal é a utilização dos poderes sobrenaturais advindos de Deus que a religião dispõe para a absolvição de toda a culpa, ou seja, a necessidade de redenção. Mas segundo Nietzsche, ao desmistificar a ideia de Deus de sua forma perfeita e punitiva que remedia a necessidade de redenção, o indivíduo não tendo mais um ser perfeito para se medir, o que o levava a se considerar imperfeito e desprezível, agora ele pode experimentar a si mesmo e se reconhecer a partir da "satisfação consigo" (GC, 290) o que o levará a ter um novo olhar para tudo o que é humano.

O que Nietzsche tem como intenção com a crítica à metafísica é destituir os conceitos absolutos, todavia o conceito de Deus como única verdade mostrando que por trás deste conceito se esconde enganos e erros. E o papel da metafísica é ser mediadora 
entre a ideia de Deus e a humanidade oferecendo a finalidade esperada, ou seja, um sentido à vida através de ideais religiosos.

Como vimos até aqui, Nietzsche toma distância da metafísica, pois a vê como um aglomerado de erros e enganos que foram tidos como verdade a partir de uma realidade suprassensível dada como algo miraculoso. Assim poderemos perceber que não existe, no indivíduo, qualquer dualismo entre corpo e alma como anuncia o ideário metafísico. Nietzsche não compreende o corpo como um sistema com uma teleologia, mas usa o termo corpo (Leib) para expressar um rompimento do dualismo entre corpo e alma e ampliar este conceito de corpo que transcende estas partes para incluir os afetos, o pensamento (a razão), os impulsos e os instintos, ou seja, o corpo é o lugar da autoexperimentação.

Nietzsche tece assim, sua crítica à filosofia como mumificação através dos conceitos. Ele acusa os filósofos de valorizarem tudo o que não tem sangue, o que não tem vida, assim ele faz uma crítica à metafísica que estabelece uma divisão entre o corpóreo e o anímico. Ele valoriza o corpo, mas não o corpo como algo que deve ser visto em detrimento da alma. Em A gaia ciência, Nietzsche se questiona "se até hoje a filosofia, de modo geral, não teria sido apenas uma interpretação do corpo e uma má-compreensão do corpo" (GC, Prefácio, 2) que foi apresentada de forma dogmática levando o homem a se eximir de qualquer explicação ou questionamento sobre si mesmo e a acreditar num mundo incondicionado o que favorece o distanciamento do homem com seu próprio mundo.

$\mathrm{O}$ "mundo incondicionado" $(\mathrm{HH}, 16)$ é um dos focos centrais da filosofia metafísica, tida, por Nietzsche, como um "erro original de todo ser orgânico" $(\mathrm{HH}, 18)$. Em outras palavras: a ideia de incondicionado teria nascido, segundo Nietzsche, da crença na liberdade da vontade, ou seja, na crença de que há uma parte do 
ser humano (a alma) que não pertence ao mundo da causalidade. A liberdade (como não condicionalidade) seria o mote central que originou a crença no mundo suprassensível. Faz sentido apresentar nesse instante o tema da liberdade atrelada à ideia do espírito livre, num viés antimetafísico para pensar o homem que se fortalece para se livrar dessas crenças e atingir uma satisfação consigo e com o mundo em que vive. Segundo Fink o espírito livre "parece ser um desmistificador capaz de dissipar as ilusões", sua frieza e desconfiança significam uma negação a qualquer tipo de idealismo e "prepara o terreno para a chegada de uma afirmação" (1988, p. 55). O espírito livre aparece como o grande cético que suspeita de tudo aquilo em que o homem mais confiava até então.

Este espíritolivreé aquele que se emancipou: de toda obrigação moral, da ideia de um mundo além deste em que vivemos, da ideia de que há um Deus e que este nos vigia a todo instante para aplicar sua ira contra nossos pecados, alias, o espírito livre já não acredita que suas ações são frutos de erros morais, causando pecados. Ele vive noutra perspectiva, no caminho da dúvida e da criação. Em oposição ao "espírito cativo" $(\mathrm{HH}, 225)$ Nietzsche afirma que o espirito livre é a exceção, não faz suas escolhas pela tradição ou hábito, pois "habituar-se a princípios intelectuais sem razão é algo que chamamos de fé" $(\mathrm{HH}, 226)$, o que não é um dos seus predicativos. O espírito livre é o homem científico, é o homem que questiona, que investiga, ele não é livre porque já se libertou e vive numa outra realidade já definida, antes ele o é porque é livre para a descoberta, para duvidar das convenções apresentadas pela moral e encontrar as origens dos acontecimentos por si mesmo através da experimentação sem medo daquilo que Nietzsche chama de vida, o que é propriamente humano.

No aforismo 16 de Humano, demasiado humano Nietzsche afirma que os "lógicos mais rigorosos" fizeram emergir "o conceito 
do metafísico como o do incondicionado" $(\mathrm{HH}, 16)$ contestando qualquer relação com o "mundo por nós conhecido". Ora, se a relação desse fragmento é direta com a filosofia kantiana, é verdade que nessa ideia Nietzsche também apoia a sua crítica à metafísica de cunho religiosa, já que a ideia de Deus é a ideia principal entre os "erros intelectuais" $(\mathrm{HH}, 16)$ herdados pela humanidade.

Essa construção de valor na qual se apoia a moral da compaixão e, em última instância, fé cristã, é uma resposta da fraqueza (fisiopsicológica) que busca combater a força de alguns poucos aristocráticos, provocando uma subversão na ordem de valores, colocando em primeiro lugar o doente, o fraco, o antinatural, ${ }^{10}$ ou seja, esta fraqueza deseja se impor como virtude levando a degeneração às forças ascendentes pois "durante algum tempo, bom e mau equivalem a nobre e baixo, senhor e escravo, mas o inimigo não é considerado mal: ele pode retribuir" $(\mathrm{HH}$, 45). Para Nietzsche o mau não é aquele que nos causa dano, mas o que é desprezível. Os fracos são aqueles que não podem, ou melhor, não se sentem capazes de enfrentar a vida como os fortes, senhores, assim se refugiam para estabelecerem leis de autoproteção e autoconsolo. O problema é que ao criarem estas leis, as constituem como "verdades absolutas" $(\mathrm{HH}, 630),{ }^{11}$ originando uma "moral da piedade" (HH, 96), ou "moral do Sermão da Montanha" (HH, 137) ${ }^{12}$ uma moral gregária, fruto do racionalismo e cristianismo imersos no mundo metafísico que em virtude da valorização da alma e do suprassensível, se esqueceram das coisas mais próximas, do corpo, da vida.

Nietzsche acredita que a ideia de Deus é uma invenção daqueles que, por medo de enfrentar as condições vitais em sua plenitude, acabaram construindo um mundo suprassensível no qual a ideia de Deus passa a significar um estágio de absoluto 
repouso, um refúgio para a sua fraqueza. Nesse sentido, a análise "científica" proposta por Nietzsche parte da pergunta sobre a necessidade fisiopsicológica da metafísica e chega à afirmação de que é a fraqueza e o medo daqueles "setores" considerados sombrios da existência que deu origem à crença no mundo suprassensível onde Deus reinaria absoluto e passaria, então, a gerenciar moralmente a realidade terrestre.

Segundo Nietzsche as características que foram designadas a este "verdadeiro ser" são "as características do nada - construiuse o "mundo moral" a partir da contradição ao "mundo físico" ( $\mathrm{HH}, 136)$. Este mundo incondicionado, construído pelos ideais é um mundo onde reina a suspeita da vida, levando o homem a buscar sempre uma vida melhor, mas encontram nesta busca uma barreira que "impedem que os homens trabalhem por uma real melhoria" ( $\mathrm{HH}, 148)$. Essa realidade criada tem seu fundamento no medo dos impulsos naturais, pois alguns homens fracos generalizaram a sua fraqueza e espalharam o seu medo inventando o incondicionado para o condicionado. É o que Nietzsche critica: por medo do indeterminado e do instável que caracterizam a vida, a modernidade tende a tornar tudo o que é distante e desconhecido em familiar, íntimo e doméstico, assentado sobre a previsibilidade promovida pela moral. Pois esta se preocupa de forma absurda a apresentar o condicionado a partir do incondicionado, mas para Nietzsche, como vimos, toda a história metafísica do ser incondicionado está pautada numa origem condicionada. Se o espírito está aprisionado pela metafísica devido ao medo da vida, o espírito livre está liberado pela coragem que nasce da afirmação de si mesmo em sua plenitude de forças. Assim o fraco, aquele designado pela moral gregária por medo da vida, busca forças no além e acredita encontrar neste 
lugar criado por uma série de erros da razão, consolo e forças, o que para Nietzsche não passa de mentira, fraqueza e doença.

A metafísica promove, então, uma desqualificação do condicionado em favor do incondicionado, associado à ideia de Deus: "Absurdidade de toda metafísica na medida onde ela deduz o condicionado do incondicionado. Pertence à natureza do pensamento que ele faz do incondicionado o corolário do condicionado, que ele inventa para ajuntar a ele (...)" (KSA 9, 8 [25]). Para corroborar com esta ideia Wotling apresenta que:

Essa necessidade de juntar uma figura do absoluto ao condicionado é, de fato, particularmente clara no caso do tratamentodeprocessosmuitocomplexos:oincondicionado toma muito genericamente a forma da unidade, como evidenciado, por exemplo, pela introdução do 'eu', do sujeito, em comparação aos pensamento múltiplos. (...). A metafísica seria então uma arte de inventar mundos imaginários para os quais o nome de Deus é o mais supremo e sublime deles. É uma arte de inventar que se traveste e quer se revelar como uma arte de descobrir (2008. p. 68).

Essa força suprema será criticada por Nietzsche quando percebe que a ciência é referida como negadora de uma unidade absoluta a partir de um lugar fora da vida - que passa a avaliar a vida: a razão não pode tudo, ela não pode determinar verdades fixas sem levar em conta a fluidez de ideias e mudanças que perpassam a vida. Se a necessidade da fuga da vida devido à fraqueza, leva o homem ao mundo do incondicionado, o resultado não é outra coisa que o adoecimento e as formas de constituição da vida como um peso, um castigo, uma penalidade, um eterno sofrimento. E é então que ele chega à ideia de que a metafísica 
é um produto da insatisfação do homem consigo mesmo e da busca contínua para se redimir da culpa que o próprio homem se envolveu crendo em mundos ultramundanos, ${ }^{13}$ metafísicos.

Para ele, tais conclusões são falsas. A grande inspiração para esta conclusão é a ideia de que o sofrimento do homem é parte do devir existencial. Por não ter forças para enfrentar esse peso existencial, o homem passa a ter ódio de tudo o que é humano, da vida que está em constante mudança. De que modo? Criando a ideia metafísica de permanência. $O$ ressentimento dos metafísicos contra a realidade inventou outra realidade. Uma realidade que despreza a multiplicidade buscando uma unidade, um atomismo que engessa a reflexão filosófica pautada pela metafísica. Ao invés de alívio, o homem sente-se cada vez mais pesado. Ao invés de cura, o que ele encontra é mais doença. E dessa forma podemos pensar a vida religiosa que é o fundamento e meio para se produzir esses ideais e constitui-los como verdades absolutas.

\section{NOTAS}

${ }^{1}$ Doutorando em Filosofia pela Pontifícia Universidade Católica do Paraná. E-mail: tiagoe.lacerda@gmail.com

${ }^{2}$ Nesse artigo usaremos as siglas convencionais para as citações dos escritos de Nietzsche: HH (Humano, Demasiado Humano, vol. I); AS (Humano, Demasiado Humano II: O Andarilho e sua Sombra; A (Aurora); GC (A Gaia Ciência).

${ }^{3} \mathrm{~A}$ ideia não é desenvolver uma filosofia da linguagem em Nietzsche, mas retratar que o discurso conduz o homem a outros caminhos onde a existência não é uma possibilidade, dando lugar ao ideário metafísico. "Mas estamos acostumados a não mais observar com precisão ali onde nos faltam as palavras, 
pois é custoso ali pensar com precisão; no passado concluía-se automaticamente que onde termina o reino das palavras também termina o reino da existência" (A, 115). Sobre A linguagem como suposta ciência conferir $(\mathrm{HH}, 11)$.

${ }^{4}$ Sobre a questão da negação da vida, é importante consultar: SAMPAIO, Evaldo; DOMINGUES, Ivan. Por que somos decadentes: afirmação e negação da vida segundo Nietzsche. Tese (doutorado) - Universidade Federal de Minas Gerais, Belo Horizonte, 2009.

${ }^{5}$ Conferir Aurora, 87, 119 e 538.

${ }^{6}$ Em Humano, demasiado humano, Nietzsche, usa uma série de expressões para denunciar o erro interpretativo promovido pela metafísica: "desvios da razão" (HH, 110); "erros da razão" (HH, 124); "complexo de arbitrariedades" (HH, 111); "invenções psicológicas" (HH, 114); "artimanha" (HH, 117); "falsa interpretação" (HH, 126); "raciocínio errado" $(\mathrm{HH}, 127)$; "interpretação falsa" (HH, 134); "não científica" (HH, 134); "psicologia falsa" (HH, 135); "aberração do raciocínio e da imaginação" (HH, 135); "estapafúrdio paradoxo" (HH, 141); e "falha no espelho" (HH, 133).

${ }^{7} \mathrm{O}$ que significa propriamente um olhar histórico para o que foi.

${ }^{8}$ Quanto a isso podemos aludir ao pensamento de Aristóteles que discursava sobre o objeto da metafísica que segundo ele em A metafísica no livro XII relaciona a proposição de que o objeto sobre o qual versa sua pesquisa é a substância, e esta de fato, têm prioridade relativamente a todos os outros modos de ser, e se todas fossem corruptíveis, então tudo o que existe também seria corruptível.

${ }^{9}$ Especificamente no segundo período de sua produção Nietzsche deixa claro sua crítica à Schopenhauer e ao cristianismo. Para o autor a moral cristã estabeleceu crenças naquilo que é eterno e imóvel, o que é contrário a vida entendida por Nietzsche que baseia na flexibilidade e no movimento. Schopenhauer e o cristianismo elegeram a compaixão como mote da moralidade, ou seja, as ações que são dotadas de valor moral são somente aquelas que levam em consideração o outro, enquanto que para Nietzsche tais ações são decorrentes de algum interesse pessoal, e salienta a não existência do altruísmo, pois a ação humana é repleta de um egoísmo. Ele pretende pensar o homem a partir de um amor a si mesmo e somente assim ele seria capaz de transbordar esse amo ao outro, mas não pela via contrária, pelo autodesprezo dizendo amar o próximo sem este amor a si. Por isso a moral da compaixão 
pretende levar o homem a se compadecer e sofrer pelo outro em detrimento do amor a si mesmo, o que segundo o filósofo alemão desvincula o sentido da própria vida levando o homem a crer que exista um amor desinteressado, que é fruto de erros da razão.

${ }^{10} \mathrm{Num}$ texto tardio de Nietzsche pode-se ler: "A moral antinatural, ou seja, quase toda moral até hoje ensinada, venerada e pregada, volta-se pelo contrário, justamente contra os instintos da vida" (CI, Moral como antinatureza, 4).

${ }^{11}$ Sobre a verdade absoluta Nietzsche explica que são como conviç̧ões que os homens têm diante da vida, mas que estes que assim procedem não são os mesmos homens do pensamento científico. Ele se encontra na idade da inocência teórica e é uma criança por mais adulto que seja em outros aspectos.

${ }^{12}$ Dando origem à moral que Nietzsche designa mais tarde como "moral rebanho" (BM, 202).

${ }^{13}$ Este mundo é aparente, $\log o$ existe um mundo verdadeiro. Este mundo é condicionado, logo existe um mundo incondicionado. Este mundo é cheio de contradições, logo existe um mundo sem contradições. Este mundo está em devir, logo existe um mundo do ser. ("Para a psicologia da metafísica" KSA 12, 8 [2], de 1887). 
A NOÇÃO DE "METAFÍSICA"A PARTIR DO ARCABOUÇO TEÓRICO DO SEGUNDO...

\section{REFERÊNCIAS}

ARISTÓTELES. Metafísica. Ensaio introdutório, texto grego com tradução ao lado e comentário de G. Reale. Tradução M. Perine. São Paulo: Loyola, 2002 (3v.).

CAMARGO, G. A. "Sobre o conceito de verdade em Nietzsche". In: Revista Trágica: estudos sobre Nietzsche. n. 2, vol. 1, p. 93-112, 2008. Disponível em: http://tragica.org/artigos/02/07-gustavocamargo.pdf.

FINK, E. A filosofia de Nietzsche. Tradução Joaquim Lourenço Duarte Peixoto. Lisboa: Presença, 1983.

GIACÓIA Junior, O. "O Platão de Nietzsche, o Nietzsche de Platão”. In: Cadernos Nietzsche. Revista de Filosofia da USP, n. 2, 1997.

GRIMM, R. H. Nietzsche's Theory of Knowledge. New York: Walter de Gruyter, 1977.

HEIDEGGER, M. Nietzsche. Tradução Marco Antônio Casanova. Rio de Janeiro: Forense, 2007. v.1.

MARTON, S. "Como ler Nietzsche? Sobre a interpretação de Patrick Wotling". In: Cadernos Nietzsche. Revista de Filosofia da USP, n. 26, 2010.

MARTON, S. Nietzsche: das forças cósmicas aos valores humanos. Belo Horizonte: Editora UFMG, 2000. 
MÜLLER-LAUTER, Wolfgang. A doutrina da vontade de poderem Nietzsche. Trad. Oswaldo Giacóia Junior. São Paulo: Annablume, 1997.

NIETZSCHE, F. W. A Gaia Ciência. Tradução Paulo César de Souza. São Paulo: Companhia das Letras, 2004.

NIETZSCHE, F. W. Além do bem e do mal. Tradução Paulo César de Souza. São Paulo: Companhia das Letras, 2004.

NIETZSCHE, F. W. Aurora. Tradução Paulo César de Souza. São Paulo: Companhia das Letras, 2004.

NIETZSCHE, F. W. Crepúsculo dos Ídolos. Tradução Paulo César de Souza. São Paulo: Companhia das Letras, 2006.

NIETZSCHE, F. W. Humano, demasiado humano - Um livro para espíritos livres. Tradução Paulo César de Souza. São Paulo: Companhia das Letras, 2005 (v. I) e 2008 (v. II).

NIETZSCHE, F. W. Sämtliche Werke. Kritische Studienausgabe (KSA). Herausgegeben von Giorgio Colli und Mazzino Montinari. München/Berlin/New York: dtv/Walter de Gruyter \& Co., 1988. (15 Einzelbänden).

OLIVEIRA. Jelson R. de. "Nietzsche e o elogio das ilusões: uma estratégia de combate à metafísica" In: Estudos Nietzsche. v. 3, n. 1, p. 9-29, 2012. Disponível em: http://www2.pucpr.br/reol/index. php/estudosnietzsche?dd1=7569\&dd99=view. 
A NOÇÃO DE "METAFÍSICA"A PARTIR DO ARCABOUÇO TEÓRICO DO SEGUNDO...

RAMACCIOTTI, Bárbara Lucchesi. "Nietzsche: fisiologia como fio condutor" In.: Estudos Nietzsche, Curitiba, v. 3, n. 1, p. 65-90, jan./jun. 2012.

WOTLING, P. La Philosophie de Lesprit libre. Introduction à Nietzsche. Paris: Flammarion, 2008. 